\title{
A Combination anti-HBV regimen using lamivudine and other agents in treatment of resistant chronic hepatitis $B$
}

\author{
Saadia Farid and Samya sweilam \\ Department of Tropical Medicine and Biochemistry. \\ National Hepatology and Tropical Medicine Research Institute.
}

\begin{abstract}
Background: Several difficulties remain in formulating treatment for chronic hepatitis B (CHB), 350 million people are chronically infected with HBV, Chronic infection with hepatitis $B$ virus accounts for an enormous burden of disease worldwide, including up to half of all cases of cirrhosis, end stage liver disease, and hepatocellular carcinoma.
\end{abstract}

Aim of the work: To maximize the elimination of the viral infection while minimizing or preventing damage to the liver cells and tissues and development of viral resistance to more antivirals.

Patients and Methods: Eighty eight patients of chronic hepatitis B virus infection with resistance to lamivudine treatment as proved by quantitative PCR (more than $200 \mathrm{IU} /$ $\mathrm{ml})$. Their age between (20-60) years, (85 males, and 3 females) were selected from the National Hepatology and Tropical Medicine Research Institute and were included in this study. The included patients were two groups, the first group 42 patients, were receiving Lamivudine, plus (Baraclude) Entecavir (tablet $0.5 \mathrm{mg} /$ day) treatment at the time of assessment. The second group 46 patients were receiving (Hepsera tablet $10 \mathrm{mg} /$ day ) Adefovir dipivoxil plus lamivudine (tablet).

All the patients were subjected to the following : thorough history and clinical examination, abdominal ultrasonography and collection of blood samples for routine liver and kidney function investigations and serological assay for $\mathrm{HBsAg}, \mathrm{HBsAb}, \mathrm{HBeAg}$, $\mathrm{HBe} A b, \mathrm{HBc} A b$ quantitative HBV DNA (PCR).

Results: Our results revealed significant differences between the two groups of patients of CHBV infection, resistant to Lamivudine drug, the first group were higher in response to a combination between Lamivudine + (Baraclude) Entecavir, than the second group who were receiving Lamivudine + (Hepsera) Adefovir dipivoxil combination therapy.

Conclusion: Our study concluded that the clinical benefit is apparent with high percentage after a combination regimen using Lamivudine + Entecavir than a combination regimen using Lamivudine + Adefovir dipivoxil for the treatment of resistant chronic hepatitis B virus who were treated with Lamivudine only before.

Recommendations: Optimal management of chronic hepatitis B,that may require long-term and sometimes lifelong treatment to maintain its clinical benefit is challenging. It is important to initiate treatment with a drug that has the least potential for induction of drug resistance as sequential monotherapy which may result in selection of multidrug resistant HBV mutatants.

Key words: A combination anti-HBV, Antiviral drug resistance, Nucleos(t)ide analogues, Lamivudine, Entecavir, Adefovir dipivoxil. 


\section{Introduction}

Antiviral drug resistance is a major limitation to the long-term use of nucleos(t)ide analogue therapy (Lok, et al., (2007). The first manifestation of antiviral resistance is virological breakthrough, which is defined as an increase in serum HBV DNA by more than $1 \log$ from nadir or the redetection of HBV DNA. Serum HBV DNA levels tend to be low initially because most antiviral drug-resistant mutants have decreased replication fitness compared to the wild-type virus but compensatory mutations that can restore replication fitness frequently emerge during continued treatment leading to a progressive increase in serum HBV DNA levels (Lok, 2011).

Entecavir is a nucleoside analogue (more specifically, a guanine analogue) that inhibits reverse transcription, DNA replication and transcription in the viral replication process. The drug's manufacturer claims that Entecavir is more efficacious than previous agents used to treat hepatitis B (Lamivudine and Adefovir) \{Sims and Woodland, 2006).

Adefovir dipivoxil (Hepsera) is a nucleotide analogue of adenosine monophosphate, which can inhibite reverse transcriptase and DNA polymerase activity \{Heathcote, et al., (1998) \& Glison, et al., (1999)\& Tsiang, et al., (1999)\}. Adefovir dipivoxil has been evaluated as primary monotherapy for patients with chronic hepatitis B and in patients who developed resistance to lamivudine, it was approved by FDA (Marcellin, et al., (2003)\& Zeng, et al., (2006).

Currently approved nucleos(t)ide analogues for the treatment of hepatitis B have very little or no direct inhibitory effect on cccDNA. The resistance of cccDNA to treatments that act primarily through inhibition of reverse transcription of pregenomic RNA and the long halflife of infected hepatocytes (and hence cccDNA) account for the high rate of viral relapse when treatment is stopped.(Ganem and Prince, 2004).

HBV is not directly cytopathic. The pathogenesis of HBV-related liver injury is determined by the interactions between the virus and the host immune response (Guidotti et al., 2006). Quiescent or inactive disease indicates that the virus is suppressed by the host immune response, In persons with chronic HBV infection, the different phases represent changes in balance between the host immune response and $\mathrm{HBV}$ replication. In chronically infected individuals, the T-cell responses are weak and poorly functional (Ferrari, et al., 1990). HBV-specific T-cells are maintained in a dysfunctional state but not deleted. Increase in HBV-specific Tcell responsiveness has been observed in patients who undergo spontaneous or treatment-related $\mathrm{HBeAg}$ seroconversion (Rehermann, et al., 1996). It should be noted that while the host immune in patients with chronic HBV infection may be ineffective in viral clearance, it can mediate liver damage (Maini et al., 2000). Thus, the immune response can be a double-edge sword.

HBV has been classified into eight genotypes (A-H) based on nucleotide sequences with varying distribution in different geographical regions, HBV genotypes may play a role in determining the activity and risk of progression of liver disease(Fung et al ., 2004). Mutations in the precore and core promoter regions are the most common naturally occurring $\mathrm{HBV}$ mutations, this mutation results in a premature stop coden, thus preventing the production of $\mathrm{HBeAg}$. It is most frequently found in association with $\mathrm{HBV}$ genotype $\mathrm{D}$, and to a lesser extent in genotypes A, F or H.( Carman et al., 1989).

\section{Patients and Methods}

Eighty eight patients with chronic HBV infection resistant to lamivudine treatments proved by quantative PCR, their age between (20-60) years, ( 85 male and 3 females ), were selected from the National Hepatology and Tropical Medicine Research Institute to be included in the study with exclusion of other chronic diseases or pregnancy. 
The included patients were two groups, the first group 42 patients were receiving lamivudine, + Baraclude (Entecavir) and the second group 46 patients were receiving lamivudine + Hepsera (Adefovir dipivoxil) at the time of assessement. All the patients were subjected to the following : through history and clinical examination, abdominal ultrasonography and collection of blood samples for the routine investigations ALT, AST, alkaline phosphatase, bilirubine, albumine, CBCs, serum creatinine and serological assay for the quantative PCR(HBV DNA), the patients examined regularly every 3 months in cases of cirrhosis and every 6 months in cases with liver free from cirrhosis, $10 \mathrm{ml}$ of venous blood samples were obtained from each patients by sterile venipuncture in dry sterile vacuatainers. After centrifugation, the serum was tested for HBsAg, HBsAb, HBeAg, HBeAb, HBcAb were done by Elisa Technique. All patients were tested by third generation Elisa, using Kits from (Dia Sorin Italy) HBsAg lot Number : 0370680 A / I, HBsAb lot Number : 9230560 A / 2, HBeAg lot Number : 0600340 A / 1, HBeAb lot Number : 0490370 B, HBV DNA was quantitated in all sera using Real time PCR (Strata gene, Taq Man Gene Expression (Applied - Biosystems - Germany). Lot Number : 139282089. The kit threshold limit is $8.8 / \mathrm{IU} / \mathrm{ml}$.

Statistical analysis : Analysis of data was done by IBM computer using SPSS (Statistical program for social science version 12) as : Description of quantitative variables as mean, SD and range \& Description of qualitative variables as numbers and percentage \&
Chi- Square test was used to compare qualitative variables between groups \& Fisher exact test was used instead of chi-square when one expected cell less than or equal 5. This was expressed as probability of value ( $\mathrm{P}$ value) the difference was considered significant if $\mathrm{P}$ value $<0.05$.

\section{Results}

The study included 88 patients, both males and females, of CHBV infection , resistant to lamivudine drug, the first group (42) patients are using Baraclude (Entecavir) + Lamivudine and the second group (46) patients are using Hepsera (Adefovir dipivoxil), for 48 weeks.

We found that: There' s no statistical significant difference that could be detected between both groups as regarding quantitative (PCR) $\mathrm{HBV}$ DNA by using Chi-Square test. (p > 0.05) table (1), Graph (1).

Table (2): illustrates the comparison between both groups as regard to response to a combination anti-HBV regimen. The responder were higher among Baraclude + lamivudine group than Hepsera + lamivudine with statistically significant difference between both grouped by using ChiSquare test. $(\mathrm{P}<0.001)$ Graph (2).

Table (3): Shows the comparison between both groups as regard seroconversion. Ther's no statistically significant difference between both groups using Fisher exact test $(\mathrm{P}>0.05)$ table (3), Graph (3).

Table (A) Illustrate HBV RNA results before and after treatment :

\begin{tabular}{|l|l|l|}
\hline $\begin{array}{l}\text { HBV DNA (Quantitative } \\
\text { value) }\end{array}$ & Baraclude group & Hepsera group \\
\hline Before treatment & $>2,000,000 \mathrm{IU}$ & $>200 \mathrm{IU}$ \\
\hline After treatment & 23 (patients) BDL & 14 (patients) BDL \\
& 10 (patients) $<200 \mathrm{IU}$ & 8 (patients) $<200 \mathrm{IU}$ \\
& 1 (patient) $<500 \mathrm{IU}$ & 1 (patient) $<500 \mathrm{IU}$ \\
\hline
\end{tabular}


A Combination....

Below detection limit estimated as $8.8 \mathrm{IU} / \mathrm{ml}{ }^{*}$

Table (1) Comparison between both groups as regard HBV DNA

\begin{tabular}{|l|l|l|l|l|}
\hline $\begin{array}{l}\text { Variable } \\
\text { HBV-DNA load }\end{array}$ & $\begin{array}{l}\text { Baraclude } \\
\mathrm{N}=42\end{array}$ & $\begin{array}{l}\text { Hepsera } \\
\mathrm{N}=46\end{array}$ & $\mathbf{X}^{\mathbf{2}}$ & $\mathbf{P}$ \\
\cline { 1 - 3 } Below detection & $23(54.7 \%)$ & $14(30.4 \%)$ & \multirow{2}{*}{0.3} & \multirow{2}{*}{$\begin{array}{l}>0.05 \\
\text { NS }\end{array}$} \\
\cline { 1 - 3 } $\mathbf{\mathbf { 2 0 0 0 } \text { IU/ml }}$ & $10(23.8 \%)$ & $8(17.4 \%)$ & & \\
\hline
\end{tabular}

This table shows no statistically significant difference could be detected between both groups as regard HBV DNA by using chi-square test

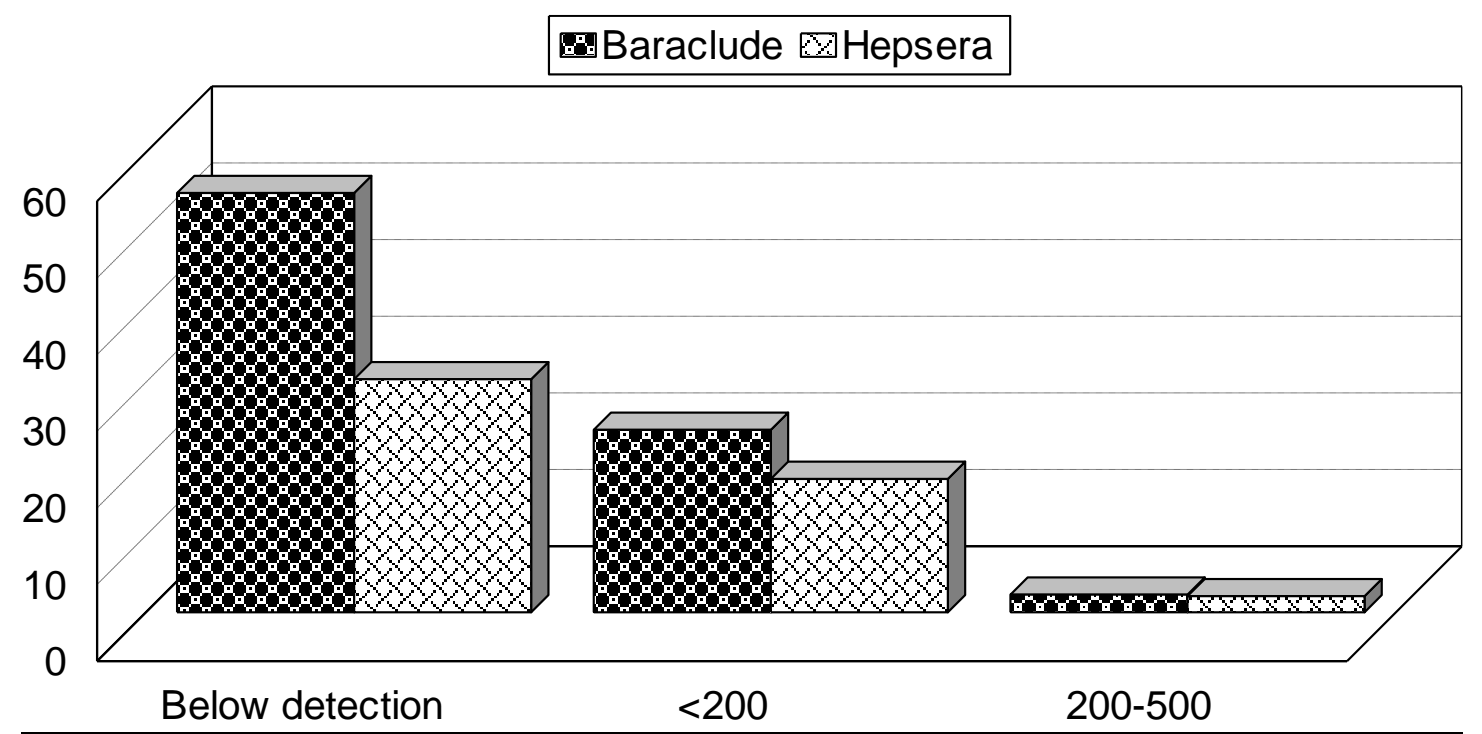

Graph (1) : Illustrate the HBV DNA IU/ml results in the sum of the two studied groups, according to chi-square results.

Table (2) Comparison between both groups as regard the response to treatments by PCR results below detection limit in the responder group.

\begin{tabular}{|l|l|l|l|l|}
\hline Variables & $\begin{array}{l}\text { Baraclude } \\
\mathrm{N}=42\end{array}$ & $\begin{array}{l}\text { Hepsera } \\
\mathrm{N}=46\end{array}$ & $\mathbf{X}^{\mathbf{2}}$ & $\mathbf{P}$ \\
\hline Responder & $34(80.9 \%)$ & $23(50 \%)$ & $\mathbf{9 . 2}$ & $\begin{array}{l}<\mathbf{0 . 0 0 1} \\
\text { HS }\end{array}$ \\
\hline Non responder & $8(19.1 \%)$ & $23(50 \%)$ & & \\
\hline
\end{tabular}

This table shows that non responder were higher among hepsera group with statistically significant difference between both groups by using chi-square test. 
Graph (2) Illusrate that the responder were higher among Baraclude group by PCR results below detection limit, according to chi-square test results.

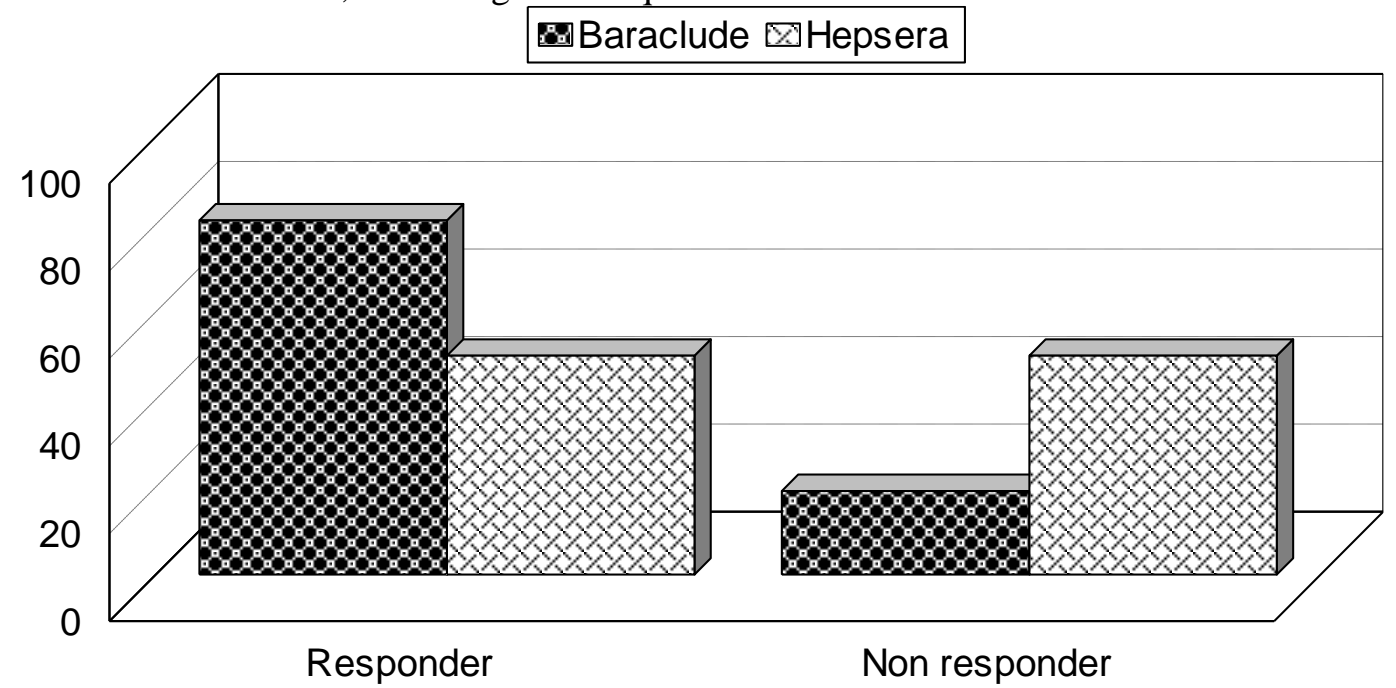

Table (3): Comparison between both groups as regard seroconversion of $\mathrm{HBeAg}(+\mathrm{ve})$ into HBeAg (- ve).

\begin{tabular}{|l|l|l|l|}
\hline Variables & $\begin{array}{l}\text { Baraclude } \\
\mathrm{N}=42\end{array}$ & $\begin{array}{l}\text { Hepsera } \\
\mathrm{N}=46\end{array}$ & P \\
\hline No conversion & $39(92.9 \%)$ & $43(93.5 \%)$ & $\begin{array}{l}>0.05 \\
\text { NS }\end{array}$ \\
\cline { 1 - 3 } Seroconversion & $3(7.1 \%)$ & $3(6.5 \%)$ & \\
\hline
\end{tabular}

This table shows no statistically significant difference between both groups by using Fisher exact test

Graph (3) Illustrate seroconversion in the sum of the two studied groups.

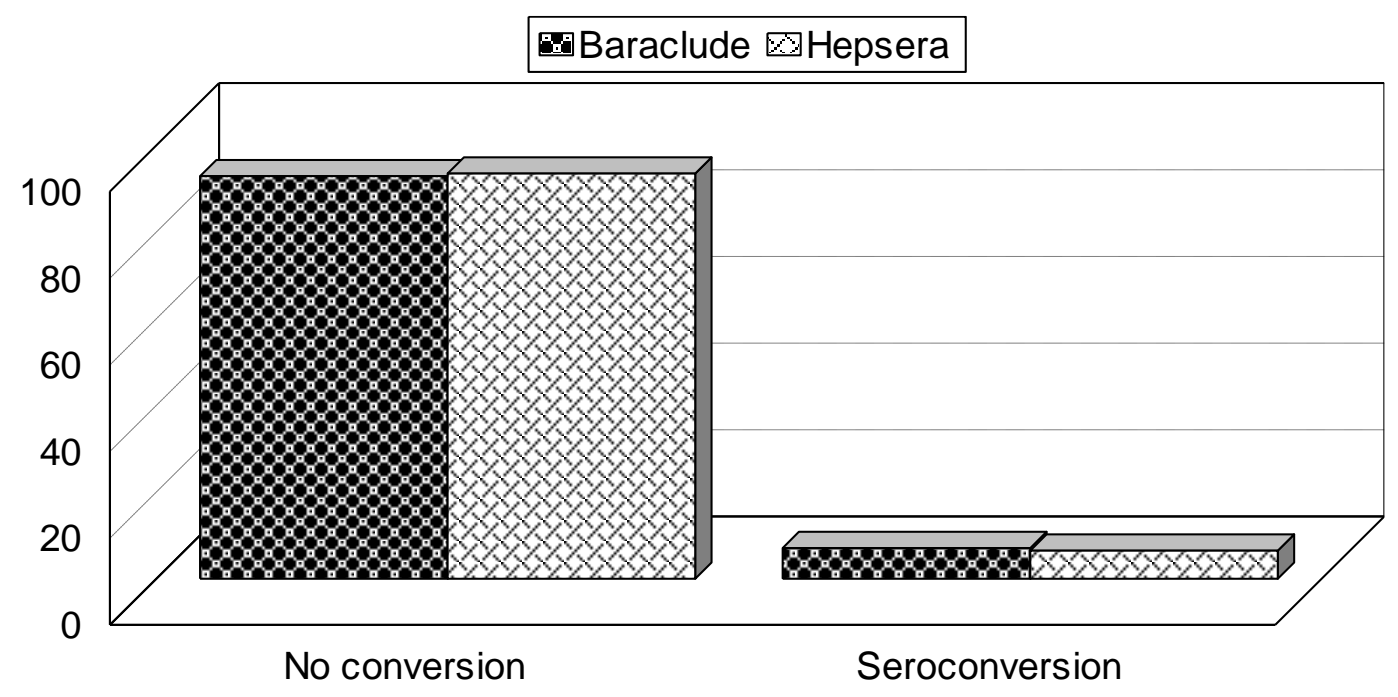




\section{Discussion}

The aims of hepatitis B treatment are to achieve sustained suppression of HBV replication and remission of liver disease. The ultimate goal is to prevent cirrhosis, liver failure and HCC. Parameters used to assess treatment response include decrease in serum HBV DNA, loss of HBsAg with or without seroconversion to anti-HBs, normalization in serum ALT, and improvement in liver histology \{ Lok, (2011)\}. The most important mutation associated with resistance to Lamivudine is a substitution of methionine for valine or isoleucine $(\mathrm{M}$ $204 \mathrm{~V} / \mathrm{I})$ in the Tyrosine-methionineaspartate (YMDD) motif. The M204 I but not the M204 V mutation is also associated the $\mathrm{rt}$ A $181 \mathrm{~T}$ mutation has also been shown to be associated with lamivudine resistance. \{Tenney, et al., (2009)\}.

This work was conducted to the serum levels of ALT, AST, ALP, albumin, bilirubin, creatinine, CBCs ( $\mathrm{Hb}$, WBCs, platelets) in compensated chronic hepatitis $B$ virus infection after treatment and find out the possible correlation with HBeAg, HBeAb, HBsAb, HBV DNA (Quantitative).

We found in our study that there is no significant difference in between patients who were receiving Baraclude $0.5 \mathrm{mg} / \mathrm{dl} /$ day or who were receiving Hepsera $10 \mathrm{mg} /$ day plus Lamivudine $100 \mathrm{mg} /$ day for 48 weeks as regard quatitative (PCR) HBV DNA at time of assessments. Several studies \{ Lia Chien, et al.,(1998) \& Dienstag, et al., (1999) \& Marcellin, et al., (2003) \& Chang, et al., (2006) \&Lai et al., (2007) \& Macellin et al., (2008)\} showed that the incidence of $\mathrm{HBV}$ genotypic antiviral resistance varies from $(0-25 \%)$ at 1 year to $1-70 \%$ at 5 years. Tenney, et al., (2009) found that resistance to Entecavir appears to occur through a two- hit mechanism. Selection of rtM204 V/ I mutation decreases susceptibility of the virus to Entecavir slightly. Additional mutations at positions 184, 202 or
250 are necessary for the manifestation of entecavir resistance. Decreased activity of Entecavir in viruses with rtM204 V/I mutation explains why the rate of Entecavir resistance is so much higher in patients with prior Lamivudine resistance. Tenney, et al., (2009) explained that mutations associated with resistance to Adefovir include substitution of Aanine for Threonine or Valine (rt A $181 \mathrm{~T} / \mathrm{V}$ ) and a substitution of Asparagine for Threonine (rt N $236 \mathrm{~T}$ ). These changes are also associated with a reduced susceptibility to Tenofovir. This results correlated with our study.

In the present study, we found that there's $54.7 \%$ of patients with HBV DNA serum load below detection limit in patients who were using Baraclude + Lamivudine after 1 year, and $30.4 \%$ in patients who were using Hepsera + Lamivudine . Lai Gane, et al., (2007) \& Marcellin, et al ., (2008) \& Hadziyannis, et al., (2003), found that a 1-year course of nucleo(t)ide analogues resulted in extremely high rates of undetectable serum HBV DNA (51-93\%). Lai, et al., (1998) \& Dienstag, et al., (1999) \& Macellin, et al., (2003) \& Chang, et al., (2006) \& Lai, et al., (2007) \& Marcellin, et al., (2008) explained that a 1year course of nucleos( $\mathrm{t}$ )ide analogues resulted in very high rates of undetectable serum HBV DNA (21-76 $\%)$. Sheman, et al., (2006) found that the magnitude of viral load reduction observed after 48 weeks of Entecavir (was $5.08 \log 10$ copies / ml). Peters, et al., (2004) added that the level of HBV DNA suppression also compared favorably to that reported in patients with Lamivudine-resistant HVB receiving Adefovir in which the mean reduction in HBV DNA was $4.00 \log$ 10 copies / ml after 1 year of treatment. These results are in agreement with our study results.

lok , ( 2011) observed that HBV nucleo(t)ide analogues Entecavir, Telbivudine and Tenofovir have more potent antiviral activity followed by Lamivudine and then Adefovir. 
Guangbi, et al., (2007) explained that Entecavir treatment for 48 weeks achieved consistent mean reductions in HBV DNA in both patients infected with HBV genotypes $\mathrm{B}(-4.96 \log 10$ cpies / $\mathrm{ml}$ ) and C ( - $5.12 \log 10$ copies / $\mathrm{ml}$ ). Among patients who received 48 weeks of Entecavir treatment, the proportion achieving HBV DNA $<0.7$ $\mathrm{MEq} / \mathrm{ml}$ was $74 \%$ and the proportion achieving HVB DNA $<300$ copies / $\mathrm{ml}$ by PCR assay was $27 \%$. Our study revealed that the responder were higher among Baraclude + Lamivudine group $(80.9 \%)$ than Hepsera + Lamivudine ( $50 \%$ ) with statistically significant difference, these results in agreement with Anna Lok whom found that Entecavir and Tenofovir are associated with the lowest rate of drug resistance, followed by Adefovir, Telbivudine Lamivudine .

Lai et al., (1998) \& Dienstag, et al., (1999) \& Macellin, et al., (2003) \& Chang, et al., (2006) \& Lai, et al., (2007) \& Marcellin, et al., (2008) postulated that a 1-year course of nucleos(t)ide analogues resulted in very high rates of undetectable serum HBV DNA (21-76 \%) and histological improvement (49- $76 \%$ ), but only $12-22 \%$ of patients achieved $\mathrm{HBeAg}$ seroconversion and only 0-3\% lost HBsAg. Yao et al., (2007) observed that among $\mathrm{HBeAg}(+)$ patient enrolled on Entecavir, the rate of $\mathrm{HBeAg}$ seroconversion after 1 year of treatment was low (6\%). Sheman, et al., (2006) explained that Furthermore, lower serologic response rates in patients who are refractory to Lamivudine are to be expected given the likelihood that patients who have remained $\mathrm{HBe} \mathrm{Ag}(+)$ despite prior Lamivudine treatment may have a decreased ability to mount an immune-mediated seroconversion response. These finding suggest that longterm therapy may be needed to achieve HBeAg seroconversion in the Lamivudine - refractory patients population. In our study seroconversion in Baraclude + Lamivudine group $7.1 \%$ and in Hepsera + Lamivudine group $(6.5 \%)$.

\section{References}

Lok AS, (2011). Hepatitis B. Sherlock's Diseases of the liver and biliary system. 12 th edition, chapter 18, p.376-392.

Caman WF, Hadziyyannis SM, Gravey MJ, italic (1989). Mutation preventing formation of hepatitis Be antigen in patients with chronic hepatitis B infection. Lancet: 2: 588591.

Chang TT, Gish RG, Man DR, italic (2006). A Comparsion of entecavir and lamivudine for $\mathrm{HBeAg}$-positive chronic hepatitis B. N. Engl. J. Med., 354:1001-1010.

Dienstag J L, Schiff ER, Wright TL, italic (1999). Lamivudine as initial treatment for chronic hepatitis B in the United States. N. Engl. J.Med., 341:1256-1263.

Ferrari C, Penna A, Benna A, Bertoletti A, italic (1990). Cellular immune response to hepatitis B virus-encoded antigens in acute and chronic hepatitis $B$ virus infection. J. Immunol., 145: 3442-3449.

Fung SK, Lok AS, (2004). Hepatitis B virus genotypes: do they play a role in the outcome of HBVinfection? Hepatology., 40: 790-792.

Ganem D, Prince AM, (2004). Hepatitis B virus infection-natural history and clinical consequences. N.Engl. Med., 350: 1118-1129.

Gilson RJ, Chopra KB, Newell AM, italic (1999). A Placebo-controlled phase 1/11 study of adefovir dipivoxil in patients with chronic hepatitis B virus infection. J viral Hepat., 6: 387.

Yao G, Zhou X, Daozheng X, Wang B, Ren H, Liu J, Dong X, and MacDonald L, (2007). Entecavir for the treatment of Lamivudinerefractory chronic hepatitis $B$ patients in China. Hepatol int., 3:373-381.

Guidotti LG, Chisari FV, (2006). Immunbiology and pathogenesis of viral hepatitis. Annu. Rev. Pathol.,1: 23-61.

Hadziyannis SJ, Tassopoulos NC, Heathcote EJ, italic (2003). Adefovir dipivoxil for the treatment of hepatitis $\mathrm{B}$ e antigen-negative chronic hepatitis B. N. Engl. J. Med., 348: 800-807.

Heathcote EJ, Jeffers L, Wright T, italic (1998). Loss of serum HBV DNA and HBeAg and seroconversion following short-term (12 weeks) adfovir dipivoxil therapy in chronic hepatitis B:Two placebo controlled phase11 studies (abstract Hepatology) 28: 317 A.

Lai C, Chien R, Leung N, (2007). A One - year trial of lamivudine for chronic hepatitis B.Asian Hepatitis Lamvudine, study group. N. Engl. J. Med., 339: 61-68.

Lai CL, Gane E, Liaw YF, italic (2007). Telbivudine versus lamivudine in patients with chronic hepatitis B. N. Engl. J. Med., 357: 2576-2588. 


\section{A Combination....}

Lok AS,. Zoulim F, Locarnini S, italic (2007). Antiviral drug-resistant HBV DNA: standardization of nomenclature and assays and recommendations for management. Hepatology., 46:254-265.

Maini MK, Lee C, Larrubia CK, italic (2000). The role of virus-specific CD8(+) cells in liver damage and viral control during persistent hepatitis B virus infection. J. Exp.Med., 191: 1269-1280.

Marcellin P, Chang T, Lim SG, italic (2003). Adefovir dipivoxil for the treatment of hepatitis Be Antigen-positive chronic hepatitis B. N. Eng. J. Med., 348: 808- 816.

Marcellin P, Healthcote EJ, Buti M, Gane E, Man DR, Krastev Z, Germanidis G, Lee SS, Flisiak R, Kaita K, Manns M, Techernov K, Buggisch P, Weilert F, Kurdas OO, Shiffman ML, Trinh $\mathrm{H}$, Washington MK, Sorbel J, Anderson J, Lampart SA, Mondou E, Quinn J, Rousseau F, (2008)\&(2009). Tenofovir disoproxil fumarate versus adefovir dipivoxil for chronic hepatitis B. N Eng J Med., 2008; 359: 2442-2455. \& J Hepatol., 2009 ;51: 416418 \& Gastrenterology. 2009; 136: 1830 1832.

Peters MG, Hann HW, Martin P, Heathcote EJ, Buggisch P, Rubin R, italic (2004). Adefovir dipivoxil alone or in combination with lamivudine in patients with lamivudine- resistant chronic hepatitis. Gastroenterology., 126:91-101.

Rehermann B, Lau D, Hoofagle JH, italic (1996). Cytotoxic $\mathrm{T}$ lymphocyte responsivness after resolution of chronic hepatitis B virus infection. J. Clin.Invest., 97: 1655-1665.

Sheman M, Yurdaydin C, Sollano J, Silva M, Liaw YF, italic (2006). Entecavir for treatment of lamivudine-refractory, $\mathrm{HBe} \mathrm{Ag}$ positive chronic hepatitis B. Gastroenterology., 130: 2039-2049.

Sims KA, Woodland AM, (December 2006). Entecavir : a new nucleoside analog for the treatment of chronic hepatitis B infection. Pharmacotherapy $26: 1745-1757$.

Tenney DJ, Rose RE, Baldick CJ, italic (2009). Long-term monitoring shows hepatitis $\mathrm{B}$ virus resistance to entecavir in nucleosidenave patients is rare through 5 year of therapy. Hepatology 49: 1503-1514.

Tsiang M, Rooney JF, Toole JJ, Gibbs CS, (1999). Biphasic Clearance Kinetics of hepatitis B virus from patients during adefovir dipivoxil therapy . Hepatology 29:1863.

Zeng M, Mao Y, Yao G, italic (2006). A Double-blind randomized Trials of adfovir dipivoxil in Chinese Subjects with $\mathrm{HBeAg}$ positive chronic hepatitis B. Hepatology 44:108. 


\section{الجمع ما بين المضادات العقاريه للفيروس الكباى الوبائى بحى الكئ

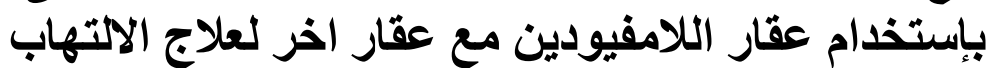

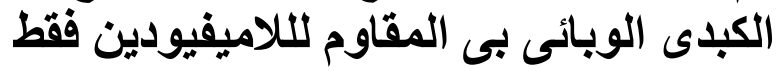 \\ سعديه فريد (قسم المتوطنه), ساميه سويلم (قسم الكيمياء الحيويه) بالمعهد القومى للكبد و الامر اض المتوطن التوطنه.}

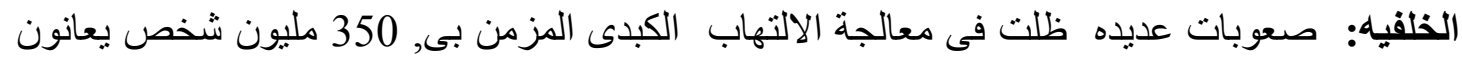

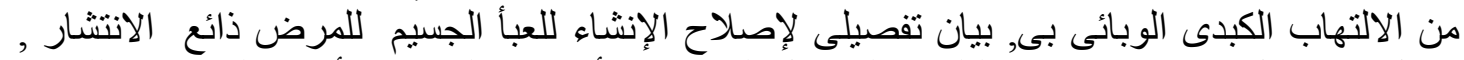

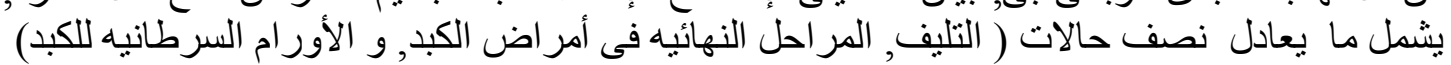

الهُف من البحث: الوصول الىى النهايه العظمى فى التخلص من الوباء الفيروسى بـى بالوصول إلى إلى الحد الأدنى له أو بمنع ( تلف الخلاياو الأنسجه الكبديه و إنتشار المقاومه للفيروس).

طريقة البحث: شملت الدراسه عدد 88 شخص من المرضى المصابين بالالتهاب الكبدى الوبائى بى و

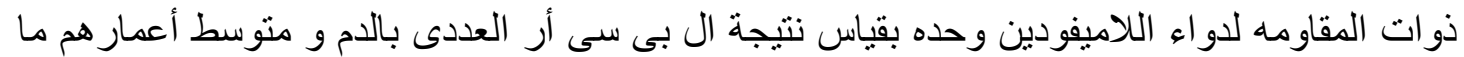

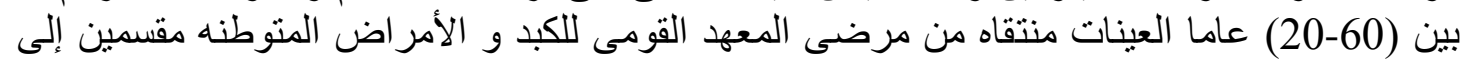

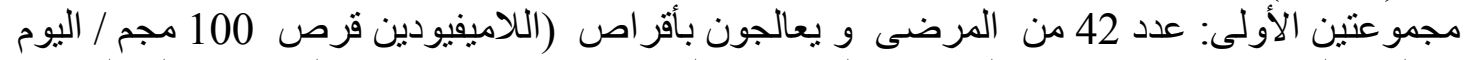

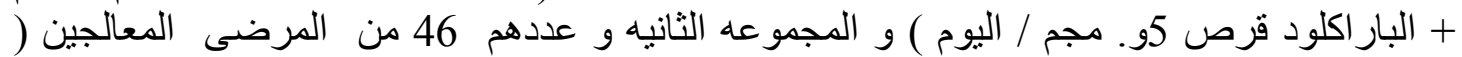

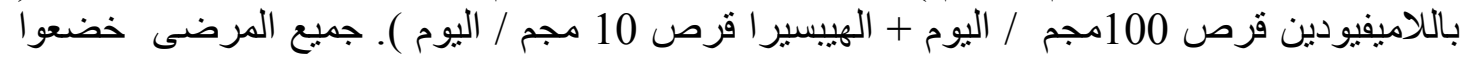

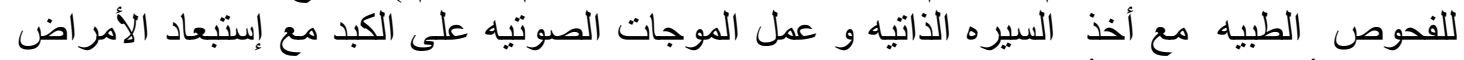

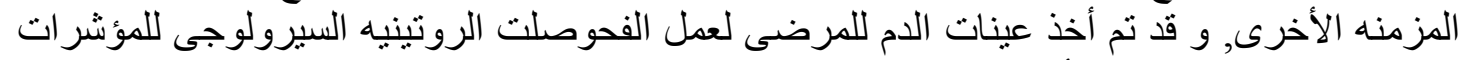

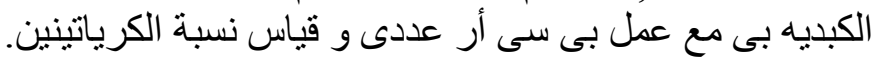

النتائج: لقد أسفرت نتائج هذه الدراسه عن وجود إستجابه إكلينيكيه لكلتا المجوعتين وهذه الإستجابه تفوق نسبياً فى المجموعه الأولى المعالجين (بالاميفيوددين+البار اكلود) بنسبة 80.9 \% \%

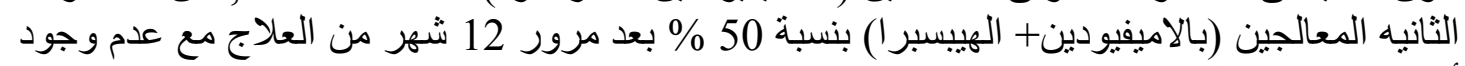

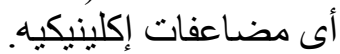

